\section{Axe the army of cheap labour}

SIR - The implication of a recent News story, "Cash rivalry 'fosters neglect of postdoc supervision'" (Nature 383, 287; 1996), that injecting more money into the National Institutes of Health or the National Science Foundation or other US funding agencies will solve the current problems of doing science, is patently wrong. There is a much deeper problem here - there are too many scientists.

The university professor is under tremendous pressure to publish a lot of papers to support his or her next grant application/renewal. Laboratories are filled with cheap labour in the form of graduate students and postdocs (particularly foreign postdocs). Unless an army of this cheap labour is in place constantly, the professor cannot publish the necessary number of papers to show apparent productivity to get funding, thus creating a vicious circle. Meanwhile, graduate schools are flooded with ever-increasing numbers of students because the professors are scrambling to feed the workers in to the vicious circle of grant-getting.

The only way to break the cycle is to reduce the number of graduate student admissions and to cut down the influx of foreign postdoc scientists. Right now the system is overloaded. The average science job opening gets hundreds of applications. In this madding crowd of scientists, nice words such as 'mentoring', 'collegiality', 'supervision' and 'teaching' are lost. The belief that Darwinian and 'market forces' will somehow correct the current problems is a fantasy. Meanwhile, highly educated hard-working scientists are underpaid and undervalued by everybody, including fellow scientists.

\section{Srin Sastry}

Laboratory of Molecular Genetics, Rockefeller University,

1230 York Avenue,

New York, New York 10021-6399, USA

SIR - The relentless decline of scientific culture, the venality of senior researchers, the torments of junior academic scientists battle-scarred by the blunderbuss of the National Institutes of Health and the National Science Foundation - these things always make news. But is it really worthwhile to devote two-thirds of a precious News page (Nature $\mathbf{3 8 3}, 287 ; 1996$ ) to the lurid - and to my mind wholly meretricious - theme of modern molecular biology postdocs oppressed by their mentors, the ageing scientists terrified by the prospect of competition from their former co-workers?

I applaud Julian Jack's initiative through the Burroughs-Wellcome Trust to award to outstanding postdoctoral researchers innovative grants that continue into their post- postdoctoral, independent research years. But I retch at the notion that this most welcome programme is motivated, as Jack claims, by a "drop-off in mentoring" because postdoctoral supervisors, these days, crudely perceive their young charges as future competitors for grant money.

There are, of course, egregious instances of emotionally insecure senior scientists thwarting their newly hatched postdocs by forbidding them to work in competitive areas. But Jack's belief that in the face of the funding crunch this odious practice is now widespread strikes me as objectively unsupported. On the contrary, most postdoctoral advisers adhere to a pervasive cultural tradition, viewing their mentoring function as a two-pronged responsibility.

First, they try to point their trainees in productive and practicable research directions. When this works, it's of great advantage to both mentor and mentored. (I frequently remind my postdocs that their only reason for existence is to make me famous.) Second, most advisers are aware that they must provide opportunities for the emergent researcher to elaborate a good project on which to make a first independent 'hit' and establish, as early as possible, a personal reputation for scientific excellence. Sometimes this means handing a pet project over to a promising beginner going into a first job and standing discreetly apart from it for a while. This is not news. Just about everyone does this without fuss or fanfare. Senior scientists who fail to do it are viewed by their peers as fundamentally deficient.

Like parents watching their children enter the adult world, most senior researchers consider that being surpassed, one-upped, outfoxed, or scooped by a former postdoc is a great joy, a talisman of success. It is this tradition that propels the fast-moving front of discovery, which by its very nature must be quickly grasped, along with the culture subsuming it, by succeed-

\section{Christopher Miller}

Department of Biochemistry, HHMI,

Brandeis University,

Waltham,

Massachusetts 02254, USA

SIR - A PhD degree, by most university standards, trains a scientist to be capable of independent research. So it is sad to read of postdoctoral scientists routinely referred to as 'students'. The freedom of postdoctoral scientists has been systematically eroded over the years and now we are looking for an excuse to justify that loss.

If it is to have any meaning, 'postdoctoral training' should mean that the postdoc has the opportunity to develop skills that ing generations. cannot be learned during a $\mathrm{PhD}$ - supervision of students or staff, developing and carrying through independent research (to the point of publication) and developing skills at collaboration.

Yet postdocs are rarely allowed the freedom to develop such skills, ironically on the basis that they are not fully fledged scientists, but students. Thus the concept of postdoctoral training actually hinders postdoctoral development.

Senior scientists conveniently forget that James Watson and Francis Crick were postdoc and student respectively when they did their Nobel prizewinning work. If the attitudes of today had existed then, would they have had the freedom to do that work or been permitted to publish without their respective group leaders? In both cases I believe the answer is 'no'. Some time between then and now, some great ideal of science, the ideal of unfettered research at all levels, has died, so gradually that no one mourned its passing.

\section{Gerard Vassiliou}

Division of Immunology and Cell Biology, John Curtin School of Medical Research, Australian National University,

GPO Box 334, Canberra ACT 2601,

Australia

e-mail: Gerard.Vassiliou@anu.edu.au

\section{Back to the roots}

SIR - It is unfortunate that the British publisher to whom Koreaki Ito submitted his paper (Nature 382, 666; 1996) still uses the spelling 'disulphide' rather than 'disulfide'. The Royal Society of Chemistry in the United Kingdom has been using the spelling 'sulfur' since 1992, and at the time of the change mentioned the desire to come into line with other English-language usage.

The name of the element is thought to have come originally from the Sanskrit word 'sulvere'. British lexicographers are thought to have taken the name of the element to have a Greek root, hence the -ph- , whereas their US counterparts took the name to have a Latin root, hence the -f-. (Interestingly, in Lassen Park in California there is a conurbation called Sulphur Works.) In the interests of homogeneity and ease of abstraction, the spelling 'sulfur' should be used by all English-language publications.

\section{David G. Morris}

Department of Chemistry,

University of Glasgow,

Glasgow G12 8QQ, UK

\section{corres@nature.com}

Letters submitted for Correspondence should be typed, double-spaced, on one side of the paper only, or e-mailed to corres@nature.com 